\title{
O ESPAÇO DA CIDADE COMO EXPRESSÃO DO ABANDONO NA OBRA DE FRANCISCO ESPINHARA
}

\author{
THE CITY SPACE AS THE EXPRESSION OF ABANDONMENT IN THE \\ WORK OF FRANCISCO ESPINHARA
}

\author{
Dr. José Eduardo Martins de Barros Melo ${ }^{1}$ \\ Jordy Dantas Maia ${ }^{2}$
}

\begin{abstract}
Resumo: Neste artigo analisa-se de que forma se constrói o estilo pessimista de Francisco Espinhara no que diz respeito às relações que sua linguagem estabelece com o mundo contemporâneo das cidades. Trata-se aqui de um estudo que pretende investigar o abandono e o espaço como recortes e marcas de uma obra cuja expressão advém da diluição do homem em suas infinitas possibilidades de solidão e isolamento frente à concretude impassível do espaço em que se insere. Acrescente-se a isso que esta obra foi escrita na efervescência do Movimento dos Escritores Independentes de Pernambuco, que em sua produção literária se identifica com o sentimento da urbe em sua intimidade. $\mathrm{O}$ trabalho, de cunho bibliográfico, toma como princípios as ideias de autores que contribuem de alguma forma a respeito da marca do pessimismo enquanto elementos de suporte da linguagem poética do autor, entre eles, Arthur Schopenhauer e o teórico da lírica moderna Hugo Friedrich. Investiga-se de que forma o autor se volta para uma obsessão incidente em sua própria existência na busca por algo que possa amparar sua solidão e sua angústia, vinculando-se a temas voltados para a poesia lírica do final do século XIX e início do século XX. Neste sentido, inserem-se o olhar de Mikhail Bakhtin e Gaston Bacherlard, enquanto aportes que sustentam parte das nossas reflexões no que diz respeito às vozes que encontramos no sujeito e suas relações com o espaço com o qual se relaciona.
\end{abstract}

Palavras-chave: Abandono, Cidade, Francisco Espinhara, Poesia, Pessimismo.

\footnotetext{
${ }^{1}$ Possui graduação em Letras pela Faculdade Frassinetti do Recife (1985), mestrado em Teoria Literária pela Universidade Estadual Paulista - São José do rio Preto (2002) e doutorado em Teoria da literatura pela Universidade Estadual Paulista -São José do rio Preto (2015). Atualmente é professor associado da Universidade Federal de Rondônia no Curso de Letras e no Mestrado Acadêmico em Estudos Literários da UNIR (PPGEL). É membro do Grupo de pesquisa em poética brasileira contemporânea (GEPEC) e Grupo de pesquisa literatura, educação e cultura: caminhos da alteridade. Tem experiência na área de Letras, com ênfase em Teoria Literária, atuando principalmente com estudos de poética.

${ }^{2}$ Acadêmico do curso de Mestrado em Estudos Literários - Universidade Federal de Rondônia - UNIR - Porto Velho - RO.
} 
Summary: This article analyzes how Francisco Espinhara pessimistic style is built with regard to the relations his language establishes with the contemporary world of cities. This is a study that intends to investigate the abandonment and space as cuts and marks of a work whose expression comes from the dilution of man in his infinite possibilities of solitude and isolation in the face of the impassive concreteness of the space in which he is inserted. In addition, this work was written in the effervescence of the Pernambuco Independent Writers Movement, which in its literary production identifies with the feeling of the city in its intimacy. This work, based on bibliographic nature, takes as its starting point the ideas of authors who contribute in some way about the mark of pessimism as supporting elements of the author's poetic language, among them Arthur Schopenhauer and the modern lyricist theorist Hugo Friedrich. It investigates how the author turns to an incident obsession in his own existence in search of something that can support his loneliness and anguish, linking himself to themes focused on lyric poetry of the late nineteenth and early twentieth century. XX. In this sense, the eyes of Mikhail Bakhtin and Gaston Bacherlard are inserted, as contributions that support part of our reflections regarding the voices we find in the subject and their relations with the space with which he relates.

Keywords: Abandonment, City, Francisco Espinhara, Poetry, Pessimism.

\section{Introdução}

"Na solidão, o solitário devora a si mesmo; Na multidão devoram-no inúmeros. Então escolhe".

(Friedrich Nietzsche)

Francisco Espinhara é um desses poetas que instiga pela expressão de sua linguagem e pelos temas que se relacionam a formatação do sujeito poético em sua essência. Oriundo do Movimento dos escritores independentes de Pernambuco nos anos de 1980 Espinhara é um autor cuja contemporaneidade se dá via relações entre espaço do abandono e a urbe em sua dimensão. Sua obra resvala em elementos que identificam o sujeito poético enquanto agente de seu isolamento e de sua solidão.

Neste trabalho analisa-se de que forma isso se dá por meio da leitura sistematizada dos poemas "Repensando", "Fantoches", "Bucolismo Urbano" (1981) e "Hay que Endurecerse" (1989), poemas cuja representatividade assume importância singular para a compreensão de sua obra enquanto espaço de representação da reclusão e do isolamento do homem moderno.

\section{A expressão do abandono e o espaço da cidade}


A lírica é apresentada, muitas vezes, como a linguagem do estado de ânimo do poeta que, por sua vez transfere-se para o espaço anímico que mesmo o homem mais solitário compartilha com todos aqueles que conseguem sentir. A poesia moderna prescinde da humanidade, no sentido tradicional, da "experiência vivida", do sentimento e, muitas vezes, do eu pessoal do artista. A cognição da lírica moderna encontra-se diante da tarefa de procurar categorias com as quais se possa descrever essa lírica. Assim, temos em Hugo Friedrich que:

A realidade desprendeu-se da ordem espacial, temporal, objetiva e anímica e subtraiu as distinções - repudiadas como prejudiciais-, que são necessárias a uma orientação anormal do universo: as distinções entre o belo e o feio, entre a proximidade e a distância, entre a luz e a sombra, entre a dor e a alegria, entre a terra e o céu. Das três maneiras possíveis de comportamento da composição lírica - sentir, observar, transformar - é esta última que domina na poesia moderna e, em verdade, tanto no que diz respeito ao mundo como na língua (FRIEDRICH, 1978, p. 17).

A lírica moderna tem suas raízes no Romantismo, momento em que os poetas adotam consciência de que a vida não poderia ser explicada pelo mecanismo próprio, pois "o universo não era uma máquina, e sim algo mais misterioso e menos racional, como também devia ser a alma humana" (DAVID ROAS, 2013, p. 07). Assim, posteriormente, a história do Simbolismo inicia quando Charles Baudelaire lê, pela primeira vez, Edgar Allan Poe em 1947. Ao procurar outros escritos de Poe, Baudelaire encontrou poemas e contos que ele tardio havia pensado "vaga e confusamente" em escrever. Por este caminho os poetas simbolistas consideraram o símbolo como o recurso para expressar o vago e multiforme mundo interno do ser humano, bem como as indagações sobre os mistérios. Desse modo, Espinhara assim como Edgar Allan Poe no conto "O homem na multidão" observa cautelosamente o espaço e as pessoas a sua volta. Nessa conjuntura, cria sua expressão poética das mais profundas e mais sombrias meditações sob a ótica pessimista transmutada pela sensação de abandono em meio ao espaço da urbe.

Homens morrem à noite em seus leitos, agarrados às mãos de confessores fantasmais, olhando-os devotamente nos olhos; morrem com o desespero no coração e um aperto na garganta, ante a horripilância de mistérios que não consentem ser revelados. (POE, 1947, p. 01) 
Nesse contexto, a linguagem simbólica na lírica moderna é o recurso que se institui, simultaneamente, como presença e ausência, algo inapreensível e misterioso, cuja realidade só pode ser pressentida. Logo, é importante ressaltar que assim como no conto "O homem na multidão" Poe extrai a inspiração de sua escrita da observação, Espinhara faz do mesmo modo. Como no trecho a seguir que se inter-relaciona com os poemas do poeta em estudo no que diz a respeito dos espaços das cidades:

O estranho se deteve e, por um momento, pareceu imerso em reflexões; depois, com evidentes sinais de agitação, seguiu em rápidas passadas um itinerário que nos levou aos limites da cidade, para regiões muito diversas daquelas que havíamos até então atravessado. (POE, 1947, p. 04)

Desse modo, os poemas de Espinhara que apresentam essa vertente pessimista de uma visão "Reticente ao trajeto branco da nuvem" (1983), são espaços simbólicos desta modernidade enquanto ponte das estruturas diluídas das cidades porque nele, o sujeito "traz uma venérea na alma e uma cova diária na mão". São reflexos de sofrimento e dor de uma atormentada maré de emoções reduzida às trevas do fôlego poético de sua vida transparente e intensa que se intensifica com a sua espacialidade. Nesse sentido, cabem as reflexões de Arthur Schopenhauer, no que se refere ao homem enquanto fenômeno do transitório em decorrência de sua morte:

O homem, como fenômeno, é transitório, sem dúvida, mas como Coisa-em-si é imperecível e reaparece, pois dele há de sobreviver um germe, um núcleo de existência, que pode vivificar-se num outro indivíduo:...A morte é o perder de uma individualidade e o obter de uma outra, por conseguinte uma mudança de individualidade sob a condução exclusiva de sua própria vontade (SCHOPENHAUER, 2000, p.128).

Esse germe do pessimismo que sobrevive dentro da poética de Espinhara e que na sua vida solitária de poeta é instrumento de inspiração para todos os seus coevos, em virtude de ser traço construtivo da escrita de uma geração em Pernambuco, contraditoriamente, também é seu pulsar no campo das positividades. Essa febre poética entrelaçada com o desejo de morrer consequentemente leva a resultados plurissignificativos da mudança de individualidade de "eus" ora por uma crença pueril no amor, ora no desamor, um por querer viver outro por desejar a morte como se fora um triunfo. 
Tal experiência já se percebe desde o seu primeiro livro, Vida Transparente (1981) em que o poema "Repensando" nos aponta os caminhos e descaminhos desta poética dialética, que sobrevive das imagens do aberto e do fechado, como aponta Barcherlard em sua Poética do Espaço (1998). Vejamos:

\section{Repensando}

Os mamões da alma, Antes de amadurecerem,

Sofrem picadas de passarinhos

(ESPINHRA, 2017, p. 141)

Neste poema, emblematicamente, o sujeito lírico, via metáforas de nivelamento, antevê o processo de amadurecimento por meio do sofrimento, das rupturas decorrentes das picadas do agente mundo, transmutado no signo "passarinho", mormente criatura inofensiva, que se transforma para se tornar agente das dores advindas do processo de amadurecimento.

Assim, a experiência do sofrimento baliza a própria morte, “A morte que não é o oposto da vida, mas um acontecimento complementar que a define. O homem, como vida, é um ser para a morte." (SCHOPENHAUER, 2000, p. 14). Da mesma forma, o poema Mandarim corrobora no sentido de expressar tal concepção por meio das dúvidas e das incertezas: "Que fazer da vida Que a vida já queda morta?’. Um questionar-se de tom irônico em meio ao seu lirismo, como forma de admitir que a vida em si já seja morta, assim como a vida em si é um ser para a morte. "A morte é propriamente o gênio inspirador, ou a musa da filosofia, pelo que Sócrates a definiu como [preparação para a morte]. Dificilmente se teria filosofado sem a morte." (SCHOPENHAUER, 2000, p. 59), assim, como para Espinhara que usufrui do seu pessimismo em meio aos espaços da morte, da vida e das cidades, como uma dominante de seu discurso que aflora em meio à necessidade de viver e sobreviver, enquanto mais uma de suas formas de fuga e superação, já que a sua própria existência se lhe parece um fardo como se vê nas reflexões de Schopenhauer:

É necessidade, carência, logo, sofrimento, ao qual consequentemente o homem está destinado originariamente pelo seu ser. Quando lhe falta o objeto do querer, retirado pela rápida e fácil satisfação, assaltam-lhe vazio e tédio aterradores, isto é, seu ser e sua existência mesma se lhe tornam um fardo 
insuportável. Sua vida, portanto, oscila como um pêndulo, para aqui e para acolá, entre a dor e o tédio (SCHOPENHAUER, 2000, § 57).

Desta forma, a melancolia tragada pelo choro de um eu notoriamente derrotista e o abandono urbano são elementos do espaço que Espinhara encarna juntamente com o sentimento de solidão em meio à cidade. Desta forma, cita-se como representação de tal condição, o poema "Fantoches", com o objetivo de ilustrar as nossas reflexões:

\section{Fantoches}

Os fantoches da rua Sete

Seguem cegos na procissão ${ }^{3}$

A puta diurna da Palma

Traz uma venérea na alma

E uma cova diária na mão

Da ponte Velha a secular ferrugem

Reticente ao trajeto branco da nuvem

Come o estrado, o arco, o vergão

Os poetas esquecidos no Beco

Transam sangue a trago seco

Dormem como trapos sobre o chão

Recife, musa, maldição

Cadela suja

Traiçoeira seta certeira

Encantada cidade do cão

(ESPINHARA, 2017 p. 105)

No que se refere ao poema "Fantoches", Eduardo Martins ratifica a ideia de que Espinhara usa elementos do espaço da urbe para construir a expressão dessa sensação de abandono em

\footnotetext{
${ }^{3}$ Esse verso é a cara do Chico Espinhara que conheci em 1980. O poeta que repudiava a tibieza das pessoas, fantoches que "seguem cegos na procissão", que sentia ira da lítero-complacência e a subserviência dos escritores alinhados com o regime militar da época. O Chico que odiava e amava a cidade fraticida com a cólera de seu verbo, o bardo que se escondia no pessimismo procurando a superação da alienação, do cultural e do intelecto. (PELLIZZI, 2017, p. 281).
} 
sua poesia e simbolicamente criar imagens na viagem do leitor formando o cenário de ruína e desamparo em meio ao ambiente que o poeta vive.

Daí certa identidade que se estabelece entre criador e processo de criação em que o ensimesmado de um se reflete na intimidade do outro e vice-versa. Não fosse isto, a poesia de Espinhara faria coletar nos espaços menos recomendados a matéria essencial do seu fazer, nos becos, saindo da boca dos bêbados e dormindo ao chão no corpo embrutecido do mendigo ou das prostitutas abandonadas, num processo de simbiose capaz de revelar a extraordinária beleza do singelo ou do inusitado associado ao grotesco. (MARTINS, 2016, p. 09).

Este canto visto por Luiz Carlos Monteiro, em orelha ao livro Eczema o lírico de Eduardo Martins (1985), como "um canto em Recife que" se descarna então para mostrar um tragicíssimo urbano diário assolado de dispneias, infâmias, tormentos, apelos, impulsos e na sua esfera mais livre e mais íntima, “cercado de males por todos os lados” representa sua agonia no espaço espelhado do cotidiano, em que transmuta sua dor em vida literária, metamorfoseada pelo olhar crítico e ensimesmado do poeta como fonte de seu processo construtivo: a "Ponte Velha" e "a secular ferrugem" simbolizando essa encrostada nostalgia que se transfigura em luz para seu espírito.

"Os poetas", "parceiros de jornada, são tragados", "esquecidos no beco", "transam sangue a trago seco" e "dormem como trapos sobre o chão". O espaço desconhecido da dúvida revela-se no olhar do observador, "Reticente ao trajeto branco da nuvem" e carcomido pela ferrugem que segue destruindo a página da esperança.

Desta forma, percebem-se as relações entre o poema "Fantoches" de Francisco Espinhara e o "Evocação do Recife" de Manuel Bandeira, a saber, que na última estrofe do poema "Fantoches" têm-se o processo de retificação às avessas: "Recife, musa, maldição cadela suja, traiçoeira seta certeira encantada cidade do cão", que expressa sua descrença com o espaço a sua volta, que parte pelo abandono e pela revolta resultante de tal condição. A verdadeira cidade é "musa, maldição" para Espinhara e "sem história nem literatura" para Manuel Bandeira.

Esse tom emotivo e nostálgico que ressalta sofrimento e dor em sua poesia enquanto representação de outras vozes é algo marcante e, porque não dizer, uma marca estilística ${ }^{4}$ que 
Espinhara imprime em seu discurso, sua expressividade ou, de acordo com a perspectiva bakthiniana:

[...] A expressividade externa abre-me o acesso ao interior do outro, permiteme fundir-me com ele por dentro. Mas será a fusão interna o objetivo principal da atividade estética para a qual a expressividade externa não seria mais que um meio, uma fonte de informação? De modo algum: para dizer a verdade, a atividade propriamente estética nem sequer começou. Com efeito, vivida internamente, a situação daquele que sofre pode levar a um ato ético - ajuda, reconforto, especulação cognitiva - e, de qualquer modo, após nos termos identificado com o outro, devemos voltar a nós mesmos, recuperar nosso próprio lugar fora daquele que sofre, sendo somente então que o material recolhido com a identificação poderá ser pensado nos planos ético, cognitivo ou estético. Se não houver essa volta a si mesmo, fica-se diante de um fenômeno patológico que consiste em viver a dor alheia como a própria dor, de um fenômeno de contaminação pela dor alheia, e nada mais. A rigor, uma identificação com o outro que acarrete a perda do lugar que somos os únicos a ocupar fora do outro é quase impossível e, em todo caso, totalmente desprovida de utilidade e de sentido. Quando me identifico com o outro, vivencio sua dor precisamente na categoria do outro, e a reação que ela suscita em mim não é o grito de dor, e sim a palavra de reconforto e o ato de assistência. Relacionar o que se viveu ao outro é a condição necessária de uma identificação e de um conhecimento produtivo, tanto ético quanto estético. (BAKHTIN, 1997, p. 45-46, itálico do autor).

É certo que Francisco Espinhara descola de sua experiência de solidão, sua experiência estética, enquanto homem que se perde dentro de si e em meio aos que o rodeia, tal qual "O homem da multidão" de Edgar Alan Poe, que observa detalhadamente cada situação, cada rosto, cada atitude, cada cena que se molda em seu universo e compõe sua poética com os resíduos da cidade.

Nesse contexto, essa poética que oscila entre os vazios e os cheios, se assim se pode falar, é precipício de uma linguagem que reflete os recortes de danos e trapos espalhados por seu chão. O Recife que corrobora para uma análise que remete não só a visão do abandono físico, pois como afirma Cida Pedrosa: "Apesar de bastante pessimista e profundamente solitário, nunca estava só. Sempre cercado por amigos, inimigos e boêmios de plantão, do meio artístico ou não", é mola propulsora e dínamo de sua poética. Essa marca de um "eu" que delimita seu território espacialmente diluído em águas insalubres e reflete a desorientação subjetiva da própria urbe, como diz Maria Elizabete Sanches em suas reflexões sobre o poema Fantoches: 
O "Fantoches", acima de qualquer suspeita, rediscute o papel do artista em seu tempo, seu trajeto "branco na nuvem", seu rastro de algo mais nos céus e na emancipação cultural da cidade, espaço que encastela o renascer das grandes discussões ideológicas praticadas em outras épocas. Desta forma, os poetas deglutem os becos e vielas que se corporificam enquanto artérias que circundam o espaço central, especialmente o "beco" que é elemento remissivo do espaço "Beco da fome", onde os Independentes se reuniam pouco antes de realizar suas atividades de rua, ora em frente às Lojas Americanas e ora em frente à Livraria Livro 7, cujo proprietário Tarcísio Pereira foi um dos seus incentivadores (SANCHES, 2015, p. 49, aspas da autora).

Disto se pode extrair não só a percepção do sujeito, mas a sua própria criação, em meio a diferentes percepções do espaço. Outro que remete a estes aspectos é o poema "Bucolismo Urbano" texto que Espinhara publicou como abertura do livro Vida Transparente (1981). Ou seja:

\section{Bucolismo Urbano}

A noite mata o dia,

A chuva abraça a noite e o asfalto,

Beija-os num beijo frio,

Alisa-os por todo corpo.

Rasga a noite, a chuva, o asfalto;

Um homem.

Cabisbaixo, mãos nos bolsos vazios, Como ele.

Caminha sem rumo, sem prumo, só [caminha;

Entre edifícios, viadutos, luzes multicores.

Só caminha, na rotina urbana.

Passa por sobre o rio, pela ponte;

Olha as águas fugindo para o mar, Com elas, os peixes, que cheiram a [detergente.

Observa que as luzes dos edifícios Refletem nas águas, brilhos falsos, propagandistas.

Olha para o céu,

Só gotas d'águas confundindo-se com 
[fumaça dos carros.

(ESPINHARA, 2017, p. 135)

O bucolismo, desfigurado pela marca da urbe, busca exaltar e descrever os costumes, as belezas, os aspectos da vida campestre, o meio rural juntamente com o urbano que é criticamente analisado pelo seu olhar poético sobre o mundo caótico e abandonado que existe e se forma cotidianamente a sua volta. Logo, essa expressão da rotina que se ocupa do homem pós-moderno remete há tempos e variações de isolamento tais como temos em "O homem da multidão" de Edgar Allan Poe.

Por isso mesmo, seu discurso faz coro com a dor e a melancolia do eu-espaço e constrói o magnífico aposto que traduz a si mesmo expressão de uma escritura úmida, como linguagem e devaneio do espírito, cujo local faz abrir as suas primeiras frestas de melancolia traduzida em "o choro, esse exercício da alma". Com isso Espinhara inicia seu desejo de modular o seu templo de desamparo, em que deuses evadidos lhe abandonam ao risco de sua maldição, o escorpião cujo veneno escamoteia o spleen da noturnidade na marca anfíbia da relação entre experiência e arte. A cidade é elemento catalisador de todas as angústias do real e resultado do enleio espiritual que deixa refletir e moldar sua amarga prova. O Recife espelha-se e espalha-se enquanto dilúvio de conflitos que deságuam as margens de um eu refugiado por opção na angústia e na rebeldia literária. (MARTINS, 2016, p. 07).

Nesse sentido, o sujeito é como alguém que caminha solitariamente em meio aos espaços que consolidam a cidade e se incorporam ao seu dia a dia, na mesma perspectiva do homem que Edgar Allan Poe constrói um ser que anda solitário e minuciosamente sem rumo e sem direção, "Um homem cabisbaixo com mãos nos bolsos vazios como ele" (Espinhara, 1981). O ser que incorpora o vazio que desagua em sua solidão, simbolicamente descrita pelo abandono da cidade também à margem de sua marginalidade e de sua própria poesia, em muitos casos, vista com desconfiança pela crítica conservadora.

Com relação à Geração Marginal, da qual Chico Espinhara é protagonista e tem o seu início de atuação histórica na década de 80 , o primeiro equívoco que se pode fazer é o de pensar que ela é composta por escritores naifs ou sem bases teóricas. (DMORAIS, 2017, p. 276).

Nessa perspectiva, faz-se uma análise relacional entre a poesia de Espinhara e a Obra "O homem da multidão" de Edgar Allan Poe para dizer-se que nunca se chegaria a uma 
conclusão exata dessa solidão urbana que permeia sua obra, sem um diálogo contextual e posicionamento comparativo. A rotina que o eu-lírico expressamente elucida em que o homem se prende ao viver e reviver as entrelinhas do concreto e suas variações, um caminhar sem rumo pelas ruas da cidade que observa os transeuntes enquanto parceiros solitários e abandonados, uma casa deformada, que não se coaduna com o espaço feliz, como nos aponta Bachelard:

Todo espaço verdadeiramente habitado traz a essência da noção de casa. Veremos, no decorrer de nossa obra, como a imaginação trabalha nesse sentido quando o ser encontrou o menor abrigo: veremos a imaginação construir "paredes" com sombras impalpáveis, reconfortar-se com ilusões de proteção ou, inversamente, tremer atrás de um grande muro, duvidar das mais sólidas muralhas. Em suma, na mais interminável dialética, o ser abrigado sensibiliza os limites de seu abrigo. Vive a casa em sua realidade e em sua virtualidade, através do pensamento e dos sonhos. (BACHELARD, 1998, p. 200).

A casa pode ser vista como um abrigo em que o poeta se recolhe para tecer sua poética, um recanto em que conversa com as ruas e demais paisagens do concreto e expõe todo lirismo nas múltiplas vozes solitárias, como devaneio que se constrói de reflexões e emoções. São estes espaços sobre o quais o sujeito se precipita e instintivamente guarda que se fundam as bases para a construção de sua poesia. É sobre eles que Bachelard constrói um dos seus pilares em “A poética do espaço", vejamos, pois:

E todos os espaços de nossas solidões passadas, os espaços em que sofremos a solidão, desfrutaram a solidão, desejamos a solidão, comprometemos a solidão, são em nós indeléveis. E é o ser precisamente que não quer apagá-los. Ele sabe por instinto que os espaços da sua solidão são constitutivos. Mesmo quando esses espaços estão para sempre riscados do presente, estranhos a todas as promessas de futuro, mesmo quando não se tem mais nenhum sótão, mesmo quando a água-furtada desapareceu, ficará para sempre o fato de termos amado um sótão, de termos vivido numa água-furtada. (BACHELARD, 1998, p. 203)

No entanto, Espinhara em seus súbitos de devaneios ${ }^{5}$ observava o caminhar das pessoas, suas escolhas, seus gestos, suas decisões nas mais simples e profanas inclinações do homem

\footnotetext{
${ }^{3}$ Ao devaneio pertencem os valores que marcam o homem em sua profundidade. O devaneio tem mesmo um privilégio de autovalorização ele desfruta diretamente seu ser. Então, os lugares... Aonde se vem o devaneio se
} 
para com a vida que levava dentro da cidade, um bucolismo paradoxal do poeta que vem como uma crítica à base material do progresso consubstancial nas cidades com base em uma ironia que pode ser observada no poema "Bucolismo Urbano".

O verdadeiro bucolismo se dá às avessas do mundo idílico do campo que estranhamente se compõe de edifícios e pontes que substituem as árvores, as luzes dos prédios refletidos nas águas e substituem o brilho das estrelas, a fumaça dos automóveis que substituem a neblina do orvalho que cobre o cerrado logo cedo e ao entardecer. Trata-se do sentimento de abandono e solidão que em Espinhara é alavanca para o fazer literário enquanto produto do seu devaneio:

Por si só, o devaneio é uma instância psíquica que frequentemente se confunde com o sonho. Mas quando se trata de um devaneio poético, de um devaneio que frui não só de si próprio, mas que prepara para outras almas deleitas poéticos, sabe-se que não se está mais diante das sonolências. O espírito pode chegar a um estado de calma, mas no devaneio poético a alma está de guarda, sem tensão, descansada e ativa. Para fazer um poema completo, bem estruturado, será preciso que o espírito o prefigure em projetos. Mas, para uma simples imagem poética, não há projeto, e não lhe é preciso mais que um movimento da alma. Numa imagem poética a alma acusa sua presença. (BACHELARD, 1998, p. 186-187).

Nesse contexto, Espinhara é um autor pessimista devido às circunstâncias existenciais e espaciais, assim como Augusto dos Anjos, que também usou de uma das pontes da cidade, para compor um dos seus mais expressivos poemas, "As cismas do destino", em que delimita a expressão da dor no trajeto da travessia. Na verdade, uma espécie de Flâneur de costas para o mudo e silencioso discurso da cidade que se incorpora a obra e a existência do sujeito, como afirma Cida Pedrosa, em um dos seus textos, "Um escritor que se fez em 100 dias" (2017):

"Não sabemos onde começa a ficção e onde entra a realidade, a vida e o poema, a narrativa e a vida. Aí, veio-me a ideia de que ele viveu na corda bamba, emocional e espiritualmente o tempo todo, sempre no limite entre o amor e o desamor. Viver e morrer. Partir ou ficar". (PEDROSA, 2017, p. 12).

reconstituem por si mesmos num novo devaneio. É justamente porque as lembranças das antigas moradias são revividas como devaneios que as moradias do passado são em nós imperecíveis. (BACHELARD, 1998, p. 201) 
É esta ideia de limites entre ficção e experiência que se extrai de "Bucolismo Urbano" em que o espaço da solidão se insere de forma mais intensa, nas margens do abandono. Uma resultante cuja origem se dá na dicotômica percepção do sujeito composta pelos valores do campo e da cidade ou ainda na dialética entre o exterior e o interior, com o objetivo de se situar no seio do espaço seguro este espaço em particular, quase sempre o atrai. Neste caso, o poeta concentra "o ser no interior dos limites que protegem" e "o jogo do exterior e da intimidade não é, no reino das imagens, um jogo equilibrado". (BACHELARD, 1998, p. 196).

Nesse contexto, o eu-lírico simbolicamente elucida, "Olha as águas fugindo para o mar, com elas, os peixes, que cheiram a detergente", traduzindo-se enquanto poluente que restringe a visibilidade e a clareza do espaço da cidade cujas "luzes dos edifícios refletem nas águas, brilhos falsos, propagandistas", capazes de em última instância remeter a certo tom de devaneio que atravessa todo poema. Daí as imagens sequenciais, tal como o correr do rio, em que o eulírico simbolicamente reflete a solidão concreta em viadutos, edifícios e outros elementos que marcam a dialética do móvel e do imóvel, que consolida outros contrastes advindos do espaço cidade, tal como a dialética do só e do acompanhado que surge no nivelamento dos vazios dos bolsos do homem e dos trajes em um instante, no mínimo, pleno: "Rasga a noite, a chuva, o asfalto; Um homem. Cabisbaixo, mãos nos bolsos vazios, como ele. Caminha sem rumo, sem prumo, só [caminha; Entre edifícios, viadutos, luzes multicores. Só caminha, na rotina urbana.” (ESPINHARA, 2017, p. 135).

Essa solidão serpenteia toda a obra de Espinhara. A sensação de vazio que encontra identidade na ideia de abandono. A expansão de se sentir invisível, um anátema do isolamento que arrasta sua intimidade cidade afora, uma alma solitária que transfere às águas do rio e as tintas da noite o espaço lúdico do desprezo e do abandono.

Trata-se do universo aleatório que se evapora na extensão da "fumaça dos automóveis" para se reencontrar nas diversas situações de seu fazer literário identificado na figura do sujeito observador. Um olhar que beira a contemplação, que partilha e participa dos movimentos que a linguagem insinua frente aos aspectos sugestivos, desenvolvidos quadro a quadro, como cenas expostas de uma intimidade, bem ao gosto da desconfiança do homem com seu próprio universo contemporâneo.

Assim Espinhara ilustra e examina minuciosamente o espaço cidade e suas verdades camufladas pelas luzes que a embelezam tornando-a elemento do mundo ilusório em que é 
necessário compor a armadura da solidão e do abandono como estratégia de sobrevivência. Desta forma, destacam-se aqui as marcas de isolamento e introspecção que advém das próprias marcas de sua poética, afinal:

Em muitas circunstâncias, deve-se reconhecer que a poesia é um compromisso da alma. A consciência associada à alma está mais fundada, menos intencionalizada do que a consciência associada aos fenômenos do espírito. Nos poemas se manifestam forças que não passam pelos circuitos de um saber. As dialéticas da inspiração e do talento tornam-se claras se considerarmos os seus dois pólos: a alma e o espírito. Em nossa opinião, alma e espírito são indispensáveis para estudar os fenômenos da imagem poética, em seus diversos matizes, a fim de que se possa seguir, sobretudo a evolução das imagens poéticas desde o devaneio até a sua execução. (BACHELARD, 1998, p. 186)

"Bucolismo Urbano" é exatamente a expressão desta alma ou deste devaneio de alma, que se espalha e espreita a solidão e seus vazios no sujeito e no outro. Assim, como afirma Octávio Paz, “A solidão é o fundo último da condição humana. O homem é o único ser que se sente só e que procura outro" também só. Essa solidão que é trazida não por ela mesma, mas pelas pessoas que vivem o entorno. Aí se encontra o nosso homem "cabisbaixo, mãos nos bolsos vazios, como ele". "Caminha sem rumo, sem prumo, só [caminha". Vale ressaltar que simbolicamente os "bolsos vazios, como ele" traduzem o espaço da solidão que abarca seu íntimo e que o eu-lírico deixa transbordar em seu instante de observação das mazelas que, em última instância circundam o seu espaço físico. São estas as mazelas que Maria Elizabete Sanches desvenda em suas reflexões sobre o poema "Fantoches":

O "Fantoches" é a representação simbólica da luta a ser travada no terreno da urbe, em seu centro, em plena Rua Sete de Setembro que representa a arena onde os gladiadores vão se defrontar e demarcar, a partir da luta, os limites de seus espaços, de onde a ocupação do espaço popular, a rua, parece ser a representação da ideologia triunfante. Mas a urbe vem com todas as suas mazelas, a venérea que assola a alma, a morte que se anuncia em cada pedaço de chão demarcado pela noite e pela escuridão, pela cegueira dos "fantoches", além da decadência expressa em sua própria constituição física aí representada pela denominação da Ponte Velha com sua "secular ferrugem". É ela que esconde a marca da tradição, os vícios do passado, o agendamento de uma postura colonizadora e coronelista da região. $\mathrm{O}$ emblema na representação do brinquedo, de sua necessidade de envolver-se em um enredo que parece não se alterar (SANCHES, 2015, p. 49). 
É isto que também se observa em outro poema do mesmo livro, "Vida transparente", que parece traduzir o vazio das avenidas no caminhar solitário do sujeito:

\author{
Entra, agora, numa avenida muito \\ [movimentada, \\ Cheia de gente com ele, \\ Cheia, mas vazia. \\ Caminha, caminha, caminha... \\ Quando dá por si, está sorrindo, feliz. \\ Sente outro cheiro: o de terra molhada.
}

(ESPINHARA, 2017 p. 136)

Nesse contexto, a felicidade se traduz no cheiro da terra molhada, no chão que o ampara em seu isolamento. Desta forma, nota-se que o poeta se regozija em seus momentos de prelúdio e de frustações, sofrimento e dor que se mesclam como polos contraditoriamente positivos do seu pessimismo como forma de vivenciar o momento de absoluta solidão.

Nesse mesmo sentido, em meio ao abandono e a relação entre a ambientação urbana e a solidão, Espinhara recorre a ponte que liga a sua poética ao universo do real, aí representado pela terra, que se traduz como amparo e elemento do "espaço feliz", como diria Bachelard. Assim, da dor e do sentimento de rara completude, constrói-se uma poética cujo núcleo central é o próprio sujeito, como se pode notar no emblemático poema que citamos abaixo extraído dos seus "Esparsos".

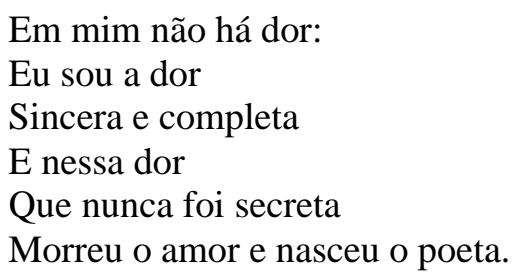

(ESPINHARA, 2017, p. 229)

Como boa parte dos poetas contemporâneos, Espinhara trabalha o despojamento da linguagem, construída em versos livres e simples, que faz uso dos elementos do cotidiano, como se percebe no texto acima. Na verdade, este traço permeia a escritura de outros poetas do Movimento, quiçá de toda uma geração que, como ele, não se alinha com o formalismo literário. É sobre isso que reflete Marcos Morais em “A geração de Francisco Espinhara”. Conforme, 
breve análise do que ele datou sobre geração marginal que Espinhara foi protagonista em sua época, junto com Eduardo Martins.

Com relação à Geração Marginal, da qual Chico Espinhara é protagonista e tem o seu início de atuação histórica na década de 80 , o primeiro equívoco que se pode fazer é o de pensar que ela é composta por escritores naifs ou sem bases teóricas. E, portanto, que não tem compromisso formal, por não empregarem os autores em suas publicações as formas clássicas, por usarem nos seus textos uma linguagem corrente, prosaica, sem rebuscamentos, trazendo as marcas da crítica social e todo o desbunde da contracultura. Mais ainda, por se utilizarem de suportes e materiais menos nobres, como a xérox e o mimeógrafo, para fazerem publicar seus poemas. E, sobretudo, por negarem as instituições literárias mais conservadoras. (DMORAIS, 2017, p. 276).

Nesse sentido, a economia das imagens e metáforas em sua poesia é substituída pela intensa e crua sensação de desabafo com palavras mais objetivas que descrevem a exatidão do seu pessimismo e a negatividade da sua visão de mundo enquanto resultante de uma obsessão poética que resgata e exalta a simplicidade e o coloquialismo. Assim, o poeta abdicou do predomínio da técnica sobre sua inspiração e se fez semelhante aos poetas de seu tempo tais como Eduardo Martins e Fátima Ferreira, entre muitos outros. Na verdade, essa simplicidade e esse coloquialismo advêm da "Boemia permanente no centro do Recife, em especial na Rua 7 de Setembro e no Beco da Fome, que marcou o poeta profundamente e lhe deixou a vontade e o gosto pelo trabalho e experiências participativas.” (PEDROSA, 2017, p. 10).

Certamente a evolução da poesia de Francisco Espinhara também se deu pelo amadurecimento poético que ele foi adquirindo conforme suas experiências de vida, como se tem em "Repensando" que simbolicamente elucida o que citamos no início destas reflexões e que obscurece a vida "transparente" encontrada em seu primeiro livro. Aqui, a sensação do real é bem mais dura, inflexível, se faz de restos da rotina da urbe, que coloca poesia e poeta em moto contínuo de isolamento, abandono e reclusão, mas que não esquece seu compromisso social e sua solidariedade para com o outro. Desta forma:

\section{Hay que Endurecerse}

Para o meu povo

Esse povo que caminha irresoluto

A mortalha, a cova, o luto 
Levando que é

Nas mãos ásperas do poder absoluto

Paga a dívida

Que sem dúvida

Alimenta o homem corrupto

Mas há uma semente

Que germina

Um rebelde fruto

Que num breve dia

Rumina

Ser mais resoluto.

(ESPINHARA, 2017, p. 116)

Um sujeito atormentado que se prende à solidão, mas ao mesmo tempo, torna-se porta voz do outro no sentido de que expressa sua revolta e seus desejos, ainda esperançosos na representação simbólica da "semente que germina" no poema e em sua voz. Trata-se de um conjunto alegórico que denuncia e aponta as mazelas do social, um uivar em protesto às somas dos agentes públicos corrompido e corruptores. Essa postura, no entanto, não serve a doutrina de nenhum segmento, foge do panteísmo barato e universaliza-se como tal.

Neste contexto sua descrença oscila entre o desabafo e o isolamento, ora proposital, ora como decorrência do abandono que permeia sua escritura e sua alma. Assim, o olhar do homem, em espaços simbólicos destas referências, capta um centro de negatividades que se incorporam ao seu discurso pessimista. Logo, esse mundo caótico que é construído de marcações visuais é o mundo "possível" que o poeta circunscreve no sentido de imprimir um retrato sem cor à cidade e a seus "Fantoches", tal como se percebe em "Hay que Endurecerse", em que a voz reconstruída e Guevara, tornam-se elementos do espírito da denúncia, "Nas mãos ásperas do poder absoluto (que) paga a dívida que sem dúvida alimenta o homem corrupto". O ciclo que alimenta as mazelas e que se movimenta no sentido do próprio sujeito.

Desta forma, "Esse povo que caminha irresoluto do poema "entra, agora, numa avenida muito movimentada, cheia, mas vazia". "Caminha, caminha, caminha..." (ESPINHARA, 2017, p. 136). “Um homem. Cabisbaixo, mãos nos bolsos vazios, Como ele. Caminha sem rumo, sem prumo, só caminha”; Do poema Bucolismo Urbano (2017, p. 135). 
Nesse sentido, é possível contextualizar sua poética atentando-se para o que representa tal contextualização, como bem nos aponta Alfredo Bosi:

\begin{abstract}
Mesmo quando o poeta fala do seu tempo, da sua experiência de homem de hoje entre homens de hoje, ele o faz, quando poeta, de um modo que não é o do senso comum, fortemente ideologizado; mas de outro, que ficou na memória infinitamente rica da linguagem. O tempo "eterno" da fala, cíclico, por isso antigo e novo, absorve, no seu código de imagens e recorrências, os dados que lhe fornece o mundo de hoje, egoísta e abstrato. Nessa perspectiva, a instância poética parece tirar do passado e da memória o direito à existência; não de um passado cronológico puro - o dos tempos já mortos - , mas de um passado presente cujas dimensões míticas se atualizam no modo de ser da infância e do inconsciente. A épica e a lírica são expressões de um tempo forte (social e individual) que já se adensou o bastante para ser reevocado pela memória da linguagem. (BOSI, 1977, p 104).
\end{abstract}

Nesse sentido, é possível interpretar que o caminho simbolicamente expresso nos versos acima é direcionado aos vários caminhos que o homem pode decidir e se ver obrigado muita das vezes a seguir sem que necessariamente encontre o seu entorno. Tal posição nos leva às reflexões de Nietzsche em Além do Bem e do Mal ou Prelúdio de uma filosofia do futuro: "E manter-se senhor das quatro virtudes: coragem, sagacidade, compaixão e solidão" (NIETZSCHE, 1886, p. 218). Essa fascinação pela solidão como uma das formas de inspiração se dá em momentos de contemplação e ensimesmamento. Sobre este processo, Nietzsche lembra que:

Percebem-se sempre nos escritos de um solitário algo como o eco do deserto, como o murmúrio e o olhar tímido da solidão, as suas expressões mais enérgicas, até seu grito, ressaltam também em uma nova espécie nova e mais perigosa de calar, o subentender. Em quem, por anos inteiros, dia e noite, permanece só com sua alma e com ela discute amigavelmente, quem em sua própria profundidade - que pode ser um labirinto ou uma mina de ouro torna-se urso em sua caverna, o caçador de tesouros, ou ainda o custódio do tesouro, o monstro que veta o acesso ao tesouro, os próprios conceitos assumem com o tempo certa cor crepuscular, recendem um odor de profundidade, um bafio de mofo, têm qualquer coisa de incomunicável e repugnante, cada qual que lhe passa nas proximidades sente uma lufada de ar frio (NIETZSCHE, 1886, p. 220).

\title{
3. Considerações finais
}


Conforme proposto neste trabalho, temos a premissa de que em Francisco Espinhara o pessimismo se faz a partir de espaços e temas voltados para o fluxo das negatividades enquanto elemento de suporte de sua expressividade. Nesse contexto, a poesia de Espinhara compõe-se desse vazio de sombras e representações simbólicas de abandono, conforme procuramos demonstrar. Sua cosmovisão fundamenta-se em suas experiências de vida, em que expressa os sentimentos sombrios da alma que permeia no espaço da cidade, enquanto expressão do abandono. Nessa conjuntura, damos ênfase ao tema aqui tratado como O Abandono e o espaço da Cidade como instrumento de decodificação de sua linguagem.

\section{Referências}

BOSI, Alfredo. O ser e o tempo da poesia. 8. ed. São Paulo: Companhia das Letras, 2000.

BACHELARD, Gaston. A poética do espaço. São Paulo: Martins Fontes, 1998.

BAKHTIN, Mikhail. Estética da criação verbal. Tradução de Maria Ermantina Galvão G. Pereira. 2. ed. São Paulo: MARTINS FONTES. 1997.

ESPINHARA, Francisco. A Poesia Possível. 1. ed. Recife: Claranan, 2017.

FRIEDICH, Hugo. Estrutura da lírica moderna: da metade do século XIX e meados do século XX. Trad. Marise M. Curisone. São Paulo: Duas cidades, 1978.

MARTINS, Eduardo. O espaço da alma em Francisco Espinhara. Porto Velho: UNIR, 2016. NIETZSCHE, Friedrich. A origem da tragédia. Trad. José Joaquim de Faria. São Paulo: centauro, 2004.

. Além do bem e do mal ou prelúdio de uma filosofia do futuro. Trad. Márcio Pugliesi, Universidade de São Paulo, 2001.

PAZ, Octavio. O labirinto da solidão e post scriptum. Tradução de Eliane Zagury. Rio de Janeiro: Paz e Terra, 1984.

POE, Edgar Allan. O Homem da Multidão. Tradução publicada na Revista da Semana, em sua ed. de 7 de novembro de 1942 .

ROAS, David. A ameaça do fantástico - aproximações teóricas. São Paulo: UNESP, 2013. SCHOPENHAUER, Arthur. O mundo como vontade e como representação. Tradução de Jair Barboza. São Paulo: UNESP, 2005. 
SANCHES, Maria Elizabete e Melo, José Eduardo Martins de Barros. Movimento dos escritores independentes de Pernambuco: história e produção literária. Porto Velho, RO: 2019.

À memória dos esquecidos: história e produção do MEIPE. UNIR, 2015.

À margem do cânone: história e produção do movimento dos escritores independentes de Pernambuco. UNIR, 2014.

. Os limites da dor em Francisco Espinhara. UNIR, 2015.

Artigo recebido em: 15.10.2019

Artigo aceito para publicar em: 9.12.2019 